\title{
The impact of therapeutic hypothermia on peripheral blood cell in newborns with hypoxic ischemic encephalopathy
}

\author{
Abdullah Kurt ${ }^{1}$, Ayşegül Zenciroğlu², Hasan Akduman ${ }^{3}$ \\ ${ }^{1}$ Department of Pediatrics Division of Neonatology, Ankara Ylldirım Beyazıt University Yenimahalle \\ Training and Research Hospital, Ankara, Turkey, ${ }^{2}$ Department of Pediatrics Division of Neonatology, \\ Sağllk Bilimleri University, Dr Sami Ulus Maternity and Children Research and Training Hospital, \\ Ankara,Turkey, ${ }^{3}$ Department of Pediatrics Division of Neonatology, Sağllk Bilimleri University, \\ Dr Sami Ulus Maternity and Children Research and Training Hospital, Ankara,Turkey
}

\begin{abstract}
The effect of hypothermia treatment on white blood cell (WBC), neutrophil-to-lymphocyte ratio (NLR), lymphocyte-to-monocyte ratio (LMR) and platelet-to-lymphocyte ratio (PLR) values as an indicator of inflammation was evaluated in newborns with hypoxic ischemic encephalopathy (HIE). The study was performed that the before-therapeutic hypothermia (TH) and after-TH WBC, lymphocytes, neutrophils, monocytes and NLR, LMR and PLR values of the complete blood cell count were retrospectively evaluated. The results of the patient group were compared with the results of healthy newborns. A total of 78 patients who underwent TH were evaluated in our study. Mean values before and after TH were NLR3.8/2.7, LMR 5.6/8.6, and PLR 60.3/67.1 respectively. A statistical significance was present for NLR values before and after TH in those with seizure in our study $(4.15 \pm 2.95 / 3.01 \pm 2.54)$ but no statistical significance was found for LMR or PLR. In neonates with HIE, effect of TH on complete blood cell count and inflammatory mechanisms (mediated neutrophil and lymphocyte) may be minimal.
\end{abstract}

Keywords: Hypoxic ischemic encephalopathy. Inflammation. Newborn.

\section{INTRODUCTION}

Hypoxic ischemic encephalopathy (HIE) is still an important problem in Neonatal Intensive Care Units despite advances in its diagnosis and treatment (Shankaran et al., 1991). Although many of the events in its pathogenesis have been explained, permanent complications are common despite treatment, especially in severe cases. The degree of hypoxia plays a major role on the mortality rate and neurodevelopment (Nelson, 2002). Among term infants, HIE due to perinatal asphyxia accounts for $20 \%$ of perinatal deaths and there is a $30 \%$ chance of disability among the survivors (Cheong et al., 2012).

\footnotetext{
*Correspondence: A. Kurt. Department of Pediatrics Division of Neonatology. Ankara Yıldırım Beyazıt University Yenimahalle Training and Research Hospital. Yeni Batı Mah. 2026 cad. 2367 sokak No:4. Batıkent Yenimahalle Ankara, Turkey. Orcid ID:0000-0002-4430-444X. Phone: +90 31258720 00. Phone: 9053333173 29. Fax: +90 31258737 75. E-mail: drabdullahkurt@yahoo.com
}

There is ample evidence that therapeutic hypothermia (TH) decreases brain injury caused by asphyxia (DouglasEscobar, Weiss, 2015). Hypothermia decreases the blood-brain barrier damage, release of excitatory neurotransmitters, free radical production, and antiinflammatory cytokine levels (Joy, et al., 2013). Several studies and biochemical markers have been used to detect the extent of multiple organ damage in infants with HIE and to determine its relationship with mortality but no definite conclusion could be reached about the prognosis (Shankaran et al., 1991; Nelson, 2002; Cheong et al., 2012; Douglas-Escobar, Weiss, 2015; Joy et al., 2013). New studies are therefore required to evaluate the factors affecting the HIE diagnosis and early stage prognosis.

Ratios of white blood cell (WBC) types have been proposed as indicators of general inflammatory responses (Naess et al., 2017). The neutrophil-tolymphocyte ratio (NLR), lymphocyte-to-monocyteratio 
(LMR), and platelet-to-lymphocyte ratio (PLR) have been proposed as potential markers of inflammation for predicting the survival of patients in various disorders including retinopathy of prematurity, neonatal sepsis, necrotizing enterocolitis, diabetic retinopathy, cancer, renal disease,cardiovascular and malignant disease, and also the mortality in patients with sepsis and chronic obstructive pulmonary disease (Naess et al., 2017; Hu, et al., 2017). The effect of TH on inflammation is already known (Cheong et al., 2012). However, its effection NLR, LMR and PLR in HIE patients has not been investigated in the literature. The effect of hypothermia treatment on WBC, NLR, LMR, and PLR values as an indicator of inflammation was evaluated in this study.

\section{MATERIAL AND METHODS}

The study was conducted on newborns who had received TH treatment for HIE at the tertiary care newborn intensive care reference center Dr. Sami Ulus Maternity, Children Health and Diseases Training Research Hospital. The before-TH and after-TH WBC, lymphocytes, neutrophils, monocytes and NLR, LMR and PLR values of the complete blood cell count were retrospectively evaluated. For complete blood cell counts, samples were taken before the start of treatment with hypothermia and within the first 24 hours after completion of the treatment with hypothermia. The gestational week, birth weight, gender, type of birth, HIE degree according to Sarnat and Sarnat (1976) staging system, presence of seizures, amplitude integrated electroencephalogram (aEEG) monitorization results, mortality and hospitalization durations of the patients were recorded. Approval was obtained from the ethics committee of the hospital for the study. Patients with chromosomal or congenital anomaly, cyanotic congenital heart disease, early neonatal sepsis (those who had growth in the first blood culture taken from all patients right after admission ( $<$ first 7 day) were excluded from the study. The criteria in Table I were used for to administer TH (Papile et al., 2014). TH was performed on patients with stage 2 or 3 HIE according to Sarnat and Sarnat (1976) staging system.

All counts were determined from the same automated blood sample measurement. The NLR, PLR, and LMR values were calculated as the ratios of the neutrophils to lymphocytes, platelets to lymphocytes, and lymphocytes to monocytes, respectively. And the peripheral blood count results of the patient group were compared with those of the control group created from healthy newborns. Healty newborns $>37$ weeks and younger than 5 days old (0-4 day) were included in the study. The control group consisted of newborns who presented to the outpatient department, with a whole blood count result for any reason, but without any disease on the history, physical examination or tests, and who were accepted as normal/healthy.

TABLE I - Therapeutic Hypothermia initiation criteria

Therapeutic Hypothermia Initiation Criteria (19)

Gestational age $\geq 35$ weeks and $\leq 6$ hours of age

AND Apgar score $\leq 5$ at 10 minutes after birth

OR Continued need for resuscitation

at 10 minutes after birth

OR $\mathrm{pH}<7.00$ or base deficit $\geq 16 \mathrm{mmol} / \mathrm{L}$ or more with an umbilical cord blood sample or an arterial or venous blood sample obtained within 60 minutes of birth

AND Moderate or severe encephalopathy on clinical examination

AND Moderately or severely abnormal background of at least 20 minutes' duration or seizure activity on aEEG after one hour of age

\section{Statistical method}

Statistical data were evaluated with SPSS, version 17. The values were given as mean \pm standard deviation. Conformance with a normal distribution was evaluated with the Kolmogorov-Smirnov test. The non-parametric and parametric tests, Wilcoxon and Paired T test were used according to the distribution of the data on statistical evaluations between the dependent variables. A p value $<0.05$ was accepted as significant.

\section{RESULTS}

A total of 78 patients who underwent $\mathrm{TH}$ were evaluated in our study. The demographic characteristics 
of the patients are presented in table II. Mean values before and after TH were WBC 20.4/9.8 $\left(\times 10^{9} / \mathrm{L}, \mathrm{p}<0.05\right)$, lymphocytes $5.0 / 2.6\left(\times 10^{9} / \mathrm{L}, \mathrm{p}<0.05\right)$, neutrophils 13.17/5.7 ( $\left.\times 10^{9} / \mathrm{L}, \mathrm{p}<0.05\right)$, monocytes $1.2 / 0.63\left(\times 10^{9} / \mathrm{L}\right.$, $\mathrm{p}<0.05)$,platelets $204 / 146\left(\times 10^{9} / \mathrm{L}, \mathrm{p}<0.05\right)$, NLR $3.8 / 2.7$ $(\mathrm{p}<0.05)$, LMR 5.6/8.6 ( $\mathrm{p}>0.05)$, and PLR 60.3/67.1 $(\mathrm{p}>0,05)$ respectively (Table III).

WBC, lymphocytes, neutrophils, monocytes, platelets, NLR, LMR, and PLR values before and after TH are presented in table III, IV, V. In our study, it was found that patients with HIE had high levels of WBC, lymphocyte and neutrophil counts before $\mathrm{TH}$, and these results were lower than those of healthy newborns after TH. Only monocyte and platelet caunts were lower than those of healthy newborns both before and after TH. WBC, lymphocytes and neutrophil increases were more important than those without seizures, whereas platelet and monocytes were significantly lower than those without seizures. Although Stage 2 and 3 patients had similar results, stage 3 had only lymphocyte increase, while WBC and neutrophil counts were lower. Platelet and monocyte counts were lower in stage 3 patients than in stage 2 .

TABLE II - Demographic characteristics of the patients

\begin{tabular}{|c|c|c|c|}
\hline & HIE group $(n=78)$ & Control group $(n=38)$ & $\mathbf{p}$ \\
\hline Gender (n, \%) & $\begin{array}{l}\text { Female: } 30(38.5) \\
\text { Male: } 48(61.5)\end{array}$ & $\begin{array}{l}\text { Female: } 21(55.3) \\
\text { Male: } 17(44.7)\end{array}$ & $* \mathrm{p}=.065$ \\
\hline Form of birth (n, \%) & $\begin{array}{c}\text { Normal vaginal route: } 40(51.3) \\
\text { Cesarean section: } 38 \text { (48.7) }\end{array}$ & $\begin{array}{l}\text { Normal vaginal route: } 19(50) \\
\text { Cesarean section: } 19(50)\end{array}$ & $* \mathrm{p}=.527$ \\
\hline $\begin{array}{l}\text { Gestational week (weeks) } \\
(\text { Mean } \pm S D)(\text { Min.-Max.) }\end{array}$ & $38.7 \pm 1.6(35-42)$ & $38.7 \pm 1.04(36-41)$ & ${ }^{\&} p=.807$ \\
\hline $\begin{array}{l}\text { Birth weight (grams) } \\
(\text { Mean } \pm S D)(\text { Min.-Max.) }\end{array}$ & $3058 \pm 584(1850-4300)$ & $3083 \pm 493(2470-4080)$ & ${ }^{*} \mathrm{p}=.703$ \\
\hline Age (postnatal day) & 0 & $2.05 \pm 1.4(0-4)$ & ${ }^{\&} p=.000$ \\
\hline
\end{tabular}

\begin{tabular}{|c|c|}
\hline Hospitalization duration (days) & $22.0 \pm 30.3(3-240)$ \\
\hline
\end{tabular}

$\begin{array}{lr}\text { HIE Stage (n, \%) } & \text { Stage } 2: 59(75.6) \\ \text { (According to Sarnat) } & \text { Stage } 3: 19(24.4)\end{array}$

(1)

(Mean \pm SD) (Min.-Max.)

Stage 3: 19 (24.4)

$\begin{array}{lll}\text { Presence of seizures (n, \%) } & Y e s: 39(50) & 0\end{array}$

No: 39 (50)

Mortality (n, \%)

Yes: 4 (5.1)

No: 74 (94.9)

*:Chi-square test, \&:Mann-Whitney U test, \#: Independent t test, HIE:Hypoxic ischemic encephalopathy 
TABLE III - The effect of Therapeutic Hypothermia on complete blood cell count in patients with HIE

\begin{tabular}{|c|c|c|c|c|c|}
\hline & $\begin{array}{c}\text { Before-TH } \\
n=78 \\
\text { Mean } \pm \text { SD } \\
\text { (Min.-max.) }\end{array}$ & $\begin{array}{c}\text { After-TH } \\
n=78 \\
\text { Mean } \pm \text { SD } \\
\text { (Min.-max.) }\end{array}$ & $p$ value & $\begin{array}{c}\text { Control } \\
\mathbf{n}=\mathbf{3 8} \\
\text { Mean } \pm \text { SD } \\
\text { (Min.-max.) }\end{array}$ & $p$ value \\
\hline WBC $\left(\times 10^{9} / \mathbf{L}\right)$ & $\begin{array}{c}20.48 \pm 6.99 \\
(7.26-42.70)\end{array}$ & $\begin{array}{c}9.80 \pm 4.55 \\
(3.55-33.52)\end{array}$ & $\mathrm{p}^{* *}<0.001$ & $\begin{array}{l}14.46 \pm 6.44 \\
(4.70-30.0)\end{array}$ & $\begin{array}{l}{ }^{8} p=.000 \\
{ }^{\&} p=.000\end{array}$ \\
\hline Lymphocytes $\left(\times 10^{9} / \mathrm{L}\right)$ & $\begin{array}{c}5.04 \pm 3.52 \\
(1.22-18.86)\end{array}$ & $\begin{array}{c}2.66 \pm 1.74 \\
(0.93-12.52)\end{array}$ & $\mathrm{p}^{*}<0.001$ & $\begin{array}{c}4.37 \pm 1.55 \\
(1.06-8.11)\end{array}$ & $\begin{array}{l}{ }^{8} p=.687 \\
{ }^{\&} p=.000\end{array}$ \\
\hline Neutrophils $\left(\times 10^{9} / \mathbf{L}\right)$ & $\begin{array}{c}13.17 \pm 5.55 \\
(2.21-30.13)\end{array}$ & $\begin{array}{c}5.73 \pm 4.15 \\
(0.61-29.15)\end{array}$ & $\mathrm{p}^{*}<0.001$ & $\begin{array}{c}7.85 \pm 5.30 \\
(1.93-20.20)\end{array}$ & $\begin{array}{l}{ }^{\&} p=.000 \\
{ }^{\#} p=.035\end{array}$ \\
\hline Monocytes $\left(\times 10^{9} / \mathbf{L}\right)$ & $\begin{array}{l}1.20 \pm 0.59 \\
(0.19-3.58)\end{array}$ & $\begin{array}{c}0.63 \pm 0.44 \\
(0.04-2.34)\end{array}$ & $\mathrm{p}^{*}<0.001$ & $\begin{array}{c}1.61 \pm 0.76 \\
(0.46-4.06)\end{array}$ & $\begin{array}{l}{ }^{8} p=.002 \\
{ }^{\&} p=.000\end{array}$ \\
\hline Platelets $\left(\times 10^{9} / \mathbf{L}\right)$ & $\begin{array}{c}204.73 \pm 74.37 \\
(30-492)\end{array}$ & $\begin{array}{c}146.48 \pm 66.76 \\
(12-293)\end{array}$ & $\mathrm{p}^{* *}<0.001$ & $\begin{array}{c}303.5 \pm 92.72 \\
(163-518)\end{array}$ & $\begin{array}{l}{ }^{\&} p=.000 \\
{ }^{\&} p=.000\end{array}$ \\
\hline NLR & $\begin{array}{c}3.82 \pm 2.67 \\
(0.26-15.22)\end{array}$ & $\begin{array}{c}2.78 \pm 2.44 \\
(0.09-14.22)\end{array}$ & $\mathrm{p}^{*}<0.001$ & $\begin{array}{c}1.96 \pm 1.44 \\
(0.29-6.99)\end{array}$ & $\begin{array}{l}{ }^{\star} \mathrm{p}=.000 \\
{ }^{\#} \mathrm{p}=.060\end{array}$ \\
\hline LMR & $\begin{array}{l}5.62 \pm 6.59 \\
(0.72-47.0)\end{array}$ & $\begin{array}{c}8.66 \pm 18.67 \\
(0.92-132.25)\end{array}$ & $\mathrm{p}^{*}=0.069$ & $\begin{array}{c}2.97 \pm 1.07 \\
(0.88-5.74)\end{array}$ & $\begin{array}{l}{ }^{\&} p=.066 \\
{ }_{p} p=.000\end{array}$ \\
\hline PLR & $\begin{array}{c}60.35 \pm 44.04 \\
(4.16-246.04)\end{array}$ & $\begin{array}{c}67.14 \pm 36.56 \\
(3.67-189.34)\end{array}$ & $\mathrm{p}^{* *}=0.180$ & $\begin{array}{c}79.88 \pm 44.32 \\
(32.11-244.34)\end{array}$ & $\begin{array}{l}{ }^{{ }} \mathrm{p}=.009 \\
{ }^{\#} \mathrm{p}=.104\end{array}$ \\
\hline
\end{tabular}

(*:Wilcoxon test, **:Paired T test, \#: Independent t test, \&: Mann-Whitney test, TH:Therapeutic Hypothermia, HIE:Hypoxic ischemic encephalopathy, WBC:White blood cell, NLR:Neutrophil-to-lymphocyte ratio, LMR:Lymphocyte-to-monocyte ratio, PLR:Platelet-tolymphocyte ratio)

TABLE IV - The effect of seizure status on complete blood cell count in patients who underwent Therapeutic Hypothermia

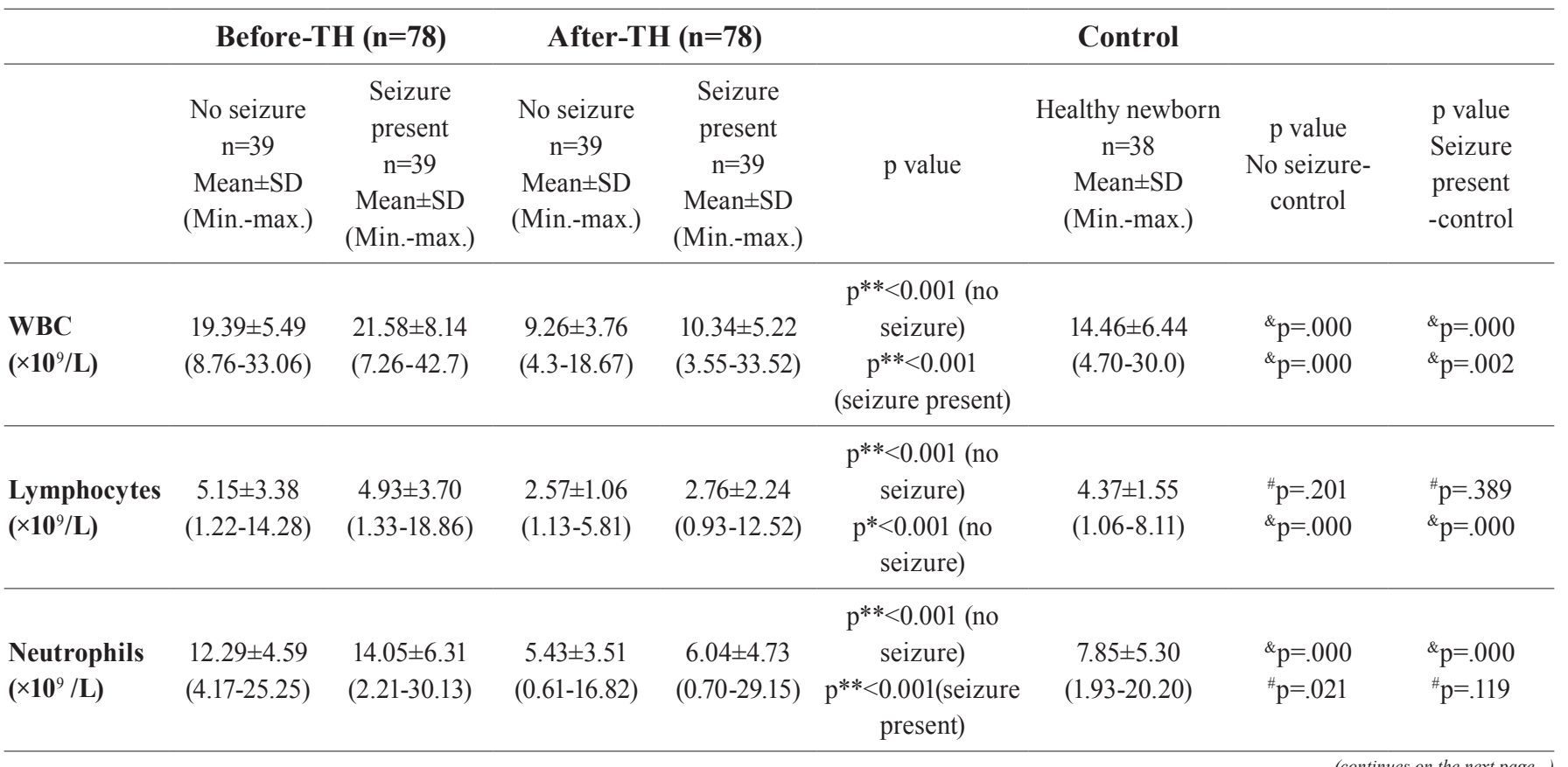


The impact of therapeutic hypothermia on peripheral blood cell in newborns with hypoxic ischemic encephalopathy

\begin{tabular}{|c|c|c|c|c|c|c|c|c|}
\hline & Before-T & $H(n=78)$ & After-TH & $H(n=78)$ & & Control & & \\
\hline $\begin{array}{l}\text { Platelets } \\
\left(\times \mathbf{1 0}^{9} / \mathbf{L}\right)\end{array}$ & $\begin{array}{c}215.71 \pm 78.36 \\
(45.0-492.0)\end{array}$ & $\begin{array}{c}193.74 \pm 69.42 \\
(30.0-342.0)\end{array}$ & $\begin{array}{c}164.92 \pm 64.20 \\
(52.0-293.0)\end{array}$ & $\begin{array}{c}128.05 \pm 64.89 \\
(12.0-280.0)\end{array}$ & $\begin{array}{c}\mathrm{p}^{* *}<0.001 \text { (no } \\
\text { seizure) } \\
\mathrm{p}^{* *<0.001} \\
\text { (seizure present) }\end{array}$ & $\begin{array}{c}303.5 \pm 92.72 \\
(163-518)\end{array}$ & $\begin{array}{l}{ }^{\&} p=.000 \\
{ }^{\&} p=.000\end{array}$ & $\begin{array}{l}{ }^{\&} p=.000 \\
{ }^{\&} p=.000\end{array}$ \\
\hline NLR & $\begin{array}{l}3.49 \pm 2.34 \\
(0.39-10.5)\end{array}$ & $\begin{array}{c}4.15 \pm 2.95 \\
(0.26-15.22)\end{array}$ & $\begin{array}{c}2.55 \pm 2.34 \\
(0.10-13.79)\end{array}$ & $\begin{array}{c}3.01 \pm 2.54 \\
(0.09-14.22)\end{array}$ & $\begin{array}{c}\mathrm{p}^{* *}=0.073 \\
\text { (no seizure) } \\
\mathrm{p}^{* *=}=0.048 \\
\text { (seizure present) }\end{array}$ & $\begin{array}{c}1.96 \pm 1.44 \\
(0.29-6.99)\end{array}$ & $\begin{array}{l}{ }^{\&} \mathrm{p}=.001 \\
{ }^{\#} \mathrm{p}=.191\end{array}$ & $\begin{array}{l}{ }^{\&} \mathrm{p}=.000 \\
{ }^{\#} \mathrm{p}=.030\end{array}$ \\
\hline PLR & $\begin{array}{l}62.20 \pm 42.16 \\
(4.16-199.18)\end{array}$ & $\begin{array}{c}58.49 \pm 46.32 \\
(5.25-246.04)\end{array}$ & $\begin{array}{c}72.57 \pm 35.18 \\
(8.89-189.34)\end{array}$ & $\begin{array}{c}61.71 \pm 37.54 \\
(3.67-171.78)\end{array}$ & $\begin{array}{c}\mathrm{p}^{* *}=0.216 \text { (no } \\
\text { seizure) } \\
\mathrm{p}^{* *}=0.581 \\
\text { (seizure present) }\end{array}$ & $\begin{array}{c}79.88 \pm 44.32 \\
(32.11-244.34)\end{array}$ & $\begin{array}{l}{ }^{\#} \mathrm{p}=.077 \\
{ }^{\#} \mathrm{p}=.425\end{array}$ & $\begin{array}{l}{ }^{\&} p=.005 \\
{ }^{\#} p=.056\end{array}$ \\
\hline
\end{tabular}

(*:Wilcoxon test, **:Paired T test, \#: Independent t test, \&: Mann-Whitney test, TH:Therapeutic Hypothermia, WBC:White blood cell, NLR:Neutrophil-to-lymphocyte ratio, LMR:Lymphocyte-to-monocyte ratio, PLR:Platelet-to-lymphocyte ratio)

TABLE V - The effect of Therapeutic Hypothermia on complete blood cell count according to the HIE stage

\section{Before-TH}

After-TH

Stage 2 HIE Stage 3 HIE Stage 2 HIE Stage 3 HIE

Mean \pm SD

(Min.-max.) $\mathrm{n}=19$

Mean \pm SD

(Min.-max.)

$$
\mathrm{n}=59
$$

Mean \pm SD

(Min.-max.) $\mathrm{n}=19$

Mean \pm SD

(Min.-max.) $\mathrm{n}=59$ $\mathrm{p}$ value

p value

$\mathrm{P} * *<0.001$

$\begin{array}{cc}19.92 \pm 5.36 & 22.25 \pm 10.58 \\ (8.40-33.06) & (7.26-42.7)\end{array}$ $\begin{array}{cc}9.91 \pm 4.51 & 9.47 \pm 4.80 \\ 4.3-33.52) & (3.55-18.46)\end{array}$
WBC $\left(\times 10^{9} / \mathrm{L}\right)$

(stage 2)

$\mathrm{P}^{* *}<0.001$

(stage 3)

$\mathrm{P}^{*}<0.001$

Lymphocytes

$\left(\times 10^{9} / \mathrm{L}\right)$

$4.42 \pm 2.75$

(1.22-13.63)

\section{$2.52 \pm 0.95$ \\ $3.09 \pm 3.13$}

(0.93-5.81)
$(1.06-12.52)$ (stage 2)

$\mathrm{p}<0.001$ (stage 3)

$\mathrm{P} * *<0.001$

(stage 2)

$\mathrm{P}^{* *}<0.001$

(stage 3)

\section{Control}

Healthy newborn $p$ value $p$ value $\mathrm{n}=38 \quad$ Stage Stage Mean \pm SD 2-control 3-control (Min.-max.)

$14.46 \pm 6.44 \quad{ }^{\&} \mathrm{p}=.000 \quad{ }^{*} \mathrm{p}=.007$

$(4.70-30.0) \quad \& \mathrm{p}=.000 \quad \& \mathrm{p}=.003$

$\begin{array}{ccc}4.37 \pm 1.55 & { }^{*} \mathrm{p}=.198 & { }^{*} \mathrm{p}=.035 \\ (1.06-8.11) & { }^{\mathrm{k}} \mathrm{p}=.000 & { }^{\mathrm{k}} \mathrm{p}=.000\end{array}$

\section{Neutrophils \\ $\left(\times 10^{9} / \mathbf{L}\right)$}

$13.5 \pm 4.60$
$(4.17-25.25)$

$12.10 \pm 7.89$

(2.21-30.13)
$5.96 \pm 4.35$

$(0.61-29.15) \quad(1.15-13.09)$
$5.05 \pm 3.45$
$(1.15-13.09)$

$\mathrm{P} * *<0.00$

(stage 2)

$\mathrm{P}^{* *}<0.001$

(stage 3)
$7.85 \pm 5.30 \quad{ }^{\&} \mathrm{p}=.000 \quad{ }^{*} \mathrm{p}=.019$

$(1.93-20.20) \quad \# \mathrm{p}=.070 \quad * \mathrm{p}=.020$

\begin{tabular}{lcccccccc}
$\begin{array}{l}\text { Monocytes } \\
\left(\times 10^{9} / \mathbf{L}\right)\end{array}$ & $1.17 \pm 0.54$ & $1.30 \pm 0.73$ & $0.67 \pm 0.46$ & $0.50 \pm 0.34$ & $($ stage 2) & $1.61 \pm 0.76$ & ${ }^{*} \mathrm{p}=.002$ & ${ }^{\#} \mathrm{p}=.154$ \\
& $(0.19-2.78)$ & $(0.44-3.58)$ & $(0.04-2.34)$ & $(0.13-1.16)$ & $\begin{array}{c}\mathrm{P}^{* *}<0.001 \\
(\text { stage 3) }\end{array}$ & $\begin{array}{c}(0.46-4.06) \\
{ }^{*} \mathrm{p}=.000\end{array}$ & ${ }^{*} \mathrm{p}=.000$ \\
\hline
\end{tabular}




\begin{tabular}{|c|c|c|c|c|c|c|c|c|}
\hline & \multicolumn{2}{|c|}{ Before-TH } & \multicolumn{2}{|c|}{ After-TH } & \multicolumn{4}{|c|}{ Control } \\
\hline Platelets $\left(\times 10^{9} / \mathbf{L}\right)$ & $\begin{array}{c}199.98 \pm 68.02 \\
(30.0-342)\end{array}$ & $\begin{array}{c}219.47 \pm 91.91 \\
(89.0-492.0)\end{array}$ & $\begin{array}{c}155.84 \pm 65.27 \\
(12.0-280.0)\end{array}$ & $\begin{array}{c}117.42 \pm 64.48 \\
(43.0-293.0)\end{array}$ & $\begin{array}{c}\mathrm{P}^{* *}<0.001 \\
\text { (stage 2) } \\
\mathrm{P}^{* *}<0.001 \\
\text { (stage 3) }\end{array}$ & $\begin{array}{c}303.5 \pm 92.72 \\
(163-518)\end{array}$ & $\begin{array}{l}{ }^{\&} p=.000 \\
{ }^{\&} p=.000\end{array}$ & $\begin{array}{l}{ }^{\&} p=.001 \\
{ }^{\&} p=.000\end{array}$ \\
\hline NLR & $\begin{array}{c}4.21 \pm 2.69 \\
(0.39-15.22)\end{array}$ & $\begin{array}{l}2.60 \pm 2.23 \\
(0.26-9.12)\end{array}$ & $\begin{array}{c}2.80 \pm 2.57 \\
(0.10-14.22)\end{array}$ & $\begin{array}{c}2.70 \pm 2.05 \\
(0.09-6.63)\end{array}$ & $\begin{array}{c}\mathrm{P}^{*}<0.001 \\
\text { (stage 2) } \\
\mathrm{P}^{* *}=0.840 \\
\text { (stage 3) }\end{array}$ & $\begin{array}{c}1.96 \pm 1.44 \\
(0.29-6.99)\end{array}$ & $\begin{array}{l}{ }^{\&} \mathrm{p}=.000 \\
{ }^{\mathrm{p}} \mathrm{p}=.069\end{array}$ & $\begin{array}{l}{ }^{\#} \mathrm{p}=.196 \\
{ }^{\#} \mathrm{p}=.174\end{array}$ \\
\hline LMR & $\begin{array}{c}5.27 \pm 6.78 \\
(0.72-47.0)\end{array}$ & $\begin{array}{c}6.72 \pm 5.96 \\
(1.67-20.73)\end{array}$ & $\begin{array}{c}7.60 \pm 17.38 \\
(0.92-132.25)\end{array}$ & $\begin{array}{l}11.93 \pm 22.40 \\
(1.91-96.31)\end{array}$ & $\begin{array}{c}\mathrm{P}^{*}=0.051 \\
\text { (stage 2) } \\
\mathrm{p}^{*}=0.717 \\
\text { (stage 3) }\end{array}$ & $\begin{array}{c}2.97 \pm 1.07 \\
(0.88-5.74)\end{array}$ & $\begin{array}{l}{ }^{\&} p=.188 \\
{ }^{\&} p=.001\end{array}$ & $\begin{array}{l}{ }^{\&} p=.023 \\
{ }^{\&} p=.286\end{array}$ \\
\hline PLR & $\begin{array}{c}63.51 \pm 45.17 \\
(4.16-246.04)\end{array}$ & $\begin{array}{c}50.52 \pm 39.84 \\
(5.25-139.85)\end{array}$ & $\begin{array}{l}68.84 \pm 35.72 \\
(5.72-189.34)\end{array}$ & $\begin{array}{l}61.88 \pm 39.59 \\
(3.67-189.34)\end{array}$ & $\begin{array}{l}\mathrm{p}=0.384 \\
\text { (stage 2) } \\
\mathrm{p}=0.197 \\
\text { (stage 3) }\end{array}$ & $\begin{array}{c}79.88 \pm 44.32 \\
(32.11-244.34)\end{array}$ & $\begin{array}{l}{ }^{\&} \mathrm{p}=.041 \\
{ }^{\#} \mathrm{p}=.180\end{array}$ & $\begin{array}{l}{ }^{\&} \mathrm{p}=.004 \\
{ }^{\#} \mathrm{p}=.140\end{array}$ \\
\hline
\end{tabular}

$(*:$ Wilcoxon test, $* *:$ Paired T test, \#:

Independent $t$ test, \&: Mann-Whitney test, TH:Therapeutic Hypothermia, HIE:Hypoxic ischemic encephalopathy, WBC:White blood cell, NLR:Neutrophil-to-lymphocyte ratio, LMR:Lymphocyte-to-monocyte ratio, PLR:Platelet-to-lymphocyte ratio)

\section{DISCUSSION}

The main causes of HIE pathogenesis are decreased brain blood flow and hypoxia (Nakajima, et al., 2000). The hypoxic ischemic event induces an inflammatory response that plays an important role in secondary neuronal injury in the brain parenchyma and in the peripheral immune system (Algra, et al., 2013). Inflammatory mediators play a critical role in the etiopathogenesis of HIE in both the process of injury and repair. It induces peripheral immune cells; activation of granulocytes, monocytes and macrophages (Li, et al., 2017). We therefore evaluated the inflammatory response using WBC, lymphocytes, neutrophils, monocytes, platelets and NLR, LMR and PLR in complete blood cell count in patients who were administered $\mathrm{TH}$ for HIE. We also investigated the relationship between the severity of the disease and complete blood cell count results. A decrease was observed in complete blood cell count results after TH in HIE patients in our study. Hudome et al. (1997) reported in their experimental neonatal rat study that neutrophils were seen in the circulation within a few hours after hypoxia-ischemia but do not pass into the brain parenchyma during the first 42 hours. By contrast, Benjelloun et al. (1999) revealed that neutrophil infiltration started the first 24 hours and peaked at 72-96 hours after hypoxic-ischemic injury. Although the studies are variable, the data suggest that neutrophil infiltration in neonatal brain is in a much less than in adults after hypoxia-ischemia (Li, et al., 2017). Hypoxia increases the number of WBC and neutrophils in the circulation. Increased cytokine and intracellular adhesion molecules accelerate local inflammatory reactions and leukocyte migration (Morkos, et al., 2007). Palmer et al reported that elevated number of neutrophil may induce damage to the vessel walls, microvascular dysfunction and poor brain damage by reducing red cell flow and oxygen delivery and subsquent leading to deterioration of energy metabolism during and after ischemia (Palmer, Roberts, Young, 2004). Palmer et al reported that neutropenia occurring prior to hypoxic ischemic insult reduced brain edema and also long-term brain injury (Palmer, Roberts, Young, 2004). However, neutropenia was reported that it was not protective when it had induced after hypoxia-ischemia (Palmer, Roberts, Young, 2004). Morkos et al reported that elevated number of peripheral neutrophil counts in the first 96 hours of 
life were associated with poor neurodevelopmental outcomes in term babies with HIE (Morkos et al., 2007). Naeye et al reported that antenatal bradycardia was correlated with lymphocytosis and increased lymphocyte count as the duration of bradycardia increased (Naeye, Shaffer, 2005). Recently, Doycheva et al suggests that coadministration granulocyte colony stimulating factor with anti-neutrophil antibodies has neuroprotective effects and prevented brain atrophy and significantly improves neurological functions by decreasing blood neutrophil caunts (Doycheva, et al., 2014). Therefore, neutrophils contribute to the exacerbation of neonatal brain damage, even though they do not immediately accumulate in the developing brain after hypoxiaischemia (Li et al., 2017; Liu, McCullough, 2013). In our study, neutrophil counts were higher than those of healthy control group before hypothermia. The number of neutrophils decreased compared to the control group after TH. In our study, the highest the number of neutrophils was found in the group with seizures. According to the HIE stage and seizure status, neutrophils were found to be low compared to the control group after $\mathrm{TH}$ before the control group.

In adult stroke models, infiltration of $\mathrm{T}$ cells into the injured brain has been showed as early as a few hours and persists days after ischemia (Brait, et al., 2010). However, in neonatal HIE models, infiltration of CD4 + and CD8 + T cells into the brain occurs in the late period and in the third phase of HIE. Infiltration of lymphocytes usually start after 24 hours and with a peak 1-2 weeks after hypoxic ischemic injury (Winerdal, et al., 2012). Winerdal et al demonstrated that activation of $\mathrm{T}$ lymphocytes is in the late period of the neonatal hypoxia-ischemia and is effective in chronic inflammation (Winerdal, et al., 2012). The low expression of the surface markers of peripheral mononuclear cells in neonates shows that they are relatively undifferentiated status (Wang, Lu, 2008). Therefore, delayed infiltration of T lymphocytes into the injured brain of newborns may be due to the immature lymphoid cells. Inflammatory processes between neonates with HIE and adult strokes are different (Li, et al., 2017; Liu, McCullough, 2013). In adult animal studies, the neurotoxic effect of T cells is known in models with acute ischemic brain injury. It is also reported that decreased $\mathrm{T}$ cell count and infiltration in adult hypoxia ischemia models reduce post ischemia infarcts (Hurn, et al., 2007). However, the effects of lymphocytes in the acute period of neonatal HIE have been reported in a small number of studies. In neonatal HIE models, it is reported that $\mathrm{T}$ cells may play a more important role in chronic inflammation (Li, et al., 2017). $\mathrm{B}$ cells are also in the process of maturation in newborns (Winerdal, et al., 2012). Winerdal et al showed that B lymphocytes were effective in chronic inflammation in neonatal hypoxia-ischemic models and especially a decrease in B lymphocyte activation and frequency was associated with larger infarctions (Winerdal, et al., 2016). Therefore, B cells may play a critical role in reducing inflammation and tissue repair in neonatal hypoxic brain injury. In the literature, lack of B cells leads to larger infarct volumes in adult stroke and increases the numbers of microglia, monocytes, and activated $\mathrm{T}$ cells in the ischemic brain (Hurn, et al., 2007; Winerdal, et al., 2016). Therefore, it may be considered that B cell protection against neonatal brain injury is most likely mediated through anti-inflammatory/immunomodulatory cytokine (Li, et al., 2017).

Since 2005, TH has been considered the standard of care for a highly selected population of near-term and term infants suffering HIE (Douglas-Escobar, Weiss, 2015; Joy, et al., 2013). In the literature, it has been suggest that $\mathrm{TH}$, in addition to directly preventing neurons from oxidative damage and apoptosis, animal and clinical studies reported that $\mathrm{TH}$ can regulate inflammatory responses and have immunosuppressive effects on neonatal HI brain injury (Douglas-Escobar, Weiss, 2015; Joy, et al., 2013). However, effect of TH on inflammation is not known (Cheong, et al., 2012). The effect of $\mathrm{TH}$ is probably related to between the severity of HIE and the balance of endogenous repair mechanisms (Rocha-Ferreira, Hristova et al., 2016). In a randomized controlled study by Jenkins et al., hypothermia in neonatal HIE has revealed associated with markedly lower counts of WBC, as well as with lower counts of neutrophils and lymphocytes lower than in patients with normothermia. Especially after treatment with hypothermia at 24-36. hours reported that WBC and ANC decreases were more pronounced and there 
was no significant change in $\mathrm{WBC}$ and $\mathrm{ANC}$ numbers during rewarming. They showed that monocyte counts were significantly reduced by hypothermia treatment. Lymphocyte counts were also reported to decrease in WBC, ANC in the hypothermia group (Jenkins, et al., 2013). In the study of Jenkins et al., the low WBC count after hypothermia treatment was associated with poor neurodevelopmental disorders in the 12 th month. In addition, in the evaluation according to the stage of HIE in neonates with HIE, it reported that TH had no effect on the, number of $\mathrm{WBC}$, neutrophils, monocytes and lymphocytes (Jenkins, et al., 2013). These results strongly suggest that $\mathrm{TH}$ regulates peripheral immune responses in neonates with HIE. In our study, it was concluded that total white blood cell count, neutrophil and monocyte counts were affected from TH treatment in the acute period. These results show that TH is effective on peripheral blood count and decreases to lower values than healthy neonates. In our study, peripheral blood results were higher in newborns with HIE compared to healthy newborns before $\mathrm{TH}$, but were lower than those in the control group after TH. In our study, the lymphocyte count was similar to the control group before hypothermia. However, there was a marked suppression of the lymphocyte count after TH. It was remarkable that the lymphocyte count was higher in stage 3 compared to stage 2 HIE neonates. Neutrophil and monocyte counts are low in patients with stage 2 after TH, which can be considered favorable in neonates with HIE. In addition, the number of neutrophils and monocytes was significantly higher in patients with seizures. Therefore, it may be suggested that neutrophils may be more important in the acute phase of HIE in the etiopathogenesis of HIE. Physiological changes occur in peripheral blood cells in newborns in the first days of life (Lambert, 2009). Normally, neutrophil count increases in the first days and decreases in the following days (Lambert, 2009). The decrease in the number of neutrophils may be related to the result of normal physiological response or in other diseases (such as infection). In our study, newborns other than HIE were excluded from the study and the results were compared with the control group. However, in the neonatal period, proportional evaluations may be more useful and reliable in the interpretation of the results because the peripheral blood results are affected by many different conditions such as postnatal week, age, sex, type of delivery or physiological changes. LMR and PLR ratios that were not statistically significant with the exception of NLR. NLR was higher in stage 2 patients than in stage 3 patients. Patients with stage 3 HIE had a lower NLR ratio, but the highest NLR values were in patients with stage 3 HIE compared to the other groups. NLR, LMR NLR was statistically significant before hypothermia. High NLR levels may be considered as poor prognosis in patients with seizures. Low NLR may be considered as a good prognosis after TH. This shows that the lymphocyte increase was slower in the early period than neutrophils. However, after TH, the fact that patients with seizures or stage 3 HIE have higher lymphocyte counts compared to other groups may be important in assessing the negative results for the chronic period. However, further studies are needed on this subject. As a result, the effect of TH on complete blood cell count in the early period of neonates with HIE may be minimal. However, the effect of TH on peripheral blood cell may have a significant effect on the long-term prognosis of patients with HIE. Further studies are required to clarify this matter.

\section{CONFLICT OF INTEREST STATEMENT}

The authors declare that there are no conflicts of interest.

- $\quad$ No funding was received

- This study was not supported by drug companies, and potential source

- $\quad$ There is no conflict of interest in the manuscript

- Approval was obtained from the local ethics committee for the study

\section{REFERENCES}

Algra SO, Groeneveld KM, Schadenberg AW, Haas F, Evens FC, Meerding J, et al. Cerebral ischemia initiates an immediate innate immune response in neonates during cardiac surgery. J Neuroinflammation. 2013;10:24.

Benjelloun N, Renolleau S, Represa A, Ben-Ari Y, Charriaut-Marlangue C. Inflammatory responses in the 
cerebral cortex after ischemia in the P7 neonatal Rat. Stroke. 1999;30(9):1916-1923 discussion 1923-1924.

Brait VH, Jackman KA, Walduck AK, Selemidis S, Diep $\mathrm{H}$, Mast AE et al. Mechanisms contributing to cerebral infarct size after stroke: gender reperfusion, $\mathrm{T}$ lymphocytes, and Nox2-derived superoxide. J Cereb Blood Flow Metab. 2010;30(7):1306-1317.

Cheong JL, Coleman L, Hunt RW, Lee KJ, Doyle LW, Inder TE, et al. Prognostic utility of magnetic resonance imaging in neonatal hypoxic-ischemic encephalopathy: sub study of a randomized trial. Arch Pediatr Adolesc Med. 2012;166(7):634-640.

Douglas-Escobar M, Weiss MD. Hypoxic-ischemic encephalopathy: a review for the clinician. JAMA Pediatr. 2015;169(4):397-403.

Doycheva DM, Hadley T, Li L, Applegate RL, Zhang JH, Tang J. Anti-neutrophil antibody enhances the neuroprotective effects of G-CSF by decreasing number of neutrophils in hypoxic ischemic neonatal rat model. Neurobiol Dis. 2014;69:192-199.

Hudome S, Palmer C, Roberts RL, Mauger D, Housman $\mathrm{C}$, Towfighi J. The role of neutrophils in the production of hypoxic-ischemic brain injury in the neonatal rat. Pediatr Res. 1997;41:607-616.

Hurn PD, Subramanian S, Parker SM, Afentoulis ME, Kaler LJ, Vandenbark AA, et al. T- and B-cell-deficient mice with experimental stroke have reduced lesion size and inflammation. J Cereb Blood Flow Metab. 2007;27:1798-1805.

Hu YX, Xu XX, Shao Y, Yuan GL, Mei F, Zhou Q, et al. The prognostic value of lymphocyte-to-monocyte ratio in retinopathy of prematurity. Int J Ophthalmol. 2017;10(11):17161721.

Jenkins DD, Lee T, Chiuzan C, Perkel JK, Rollins LG, Wagner CL, et al. Altered circulating leukocytes and their chemokines in a clinical trial of therapeutic hypothermia for neonatal hypoxic ischemic encephalopathy. Pediatr Crit Care Med. 2013;14(8):786-795.

Joy R, Pournami F, Bethou A, Bhat VB, Bobby Z. Effect of therapeutic hypothermia on oxidative stress and outcome in term neonates with perinatal asphyxia: a randomized controlled trial. J Trop Pediatr. 2013;59(1):17-22.

Lambert RM, Baer VL, Wiedmeier SE, Henry E, Burnett $\mathrm{J}$, Christensen RD. Isolated elevated blood neutrophil concentration at altitude does not require NICU admission if appropriate reference ranges are used. J Perinatol. 2009;29(12):822-825.

Li B, Concepcion K, Meng X, Zhang L. Brain-immune interactions in perinatal hypoxic-ischemic brain injury. Progr Neurobiol. 2017;159:50-68.
Liu F, McCullough LD. Inflammatory responses in hypoxic ischemic encephalopathy. Acta Pharmacol Sin. 2013;34(9):1121-30.

Morkos AA, Hopper AO, Deming DD, Yellon SM, Wycliffe $\mathrm{N}$, Ashwal S, et al. Elevated total peripheral leukocyte count may identify risk for neurological disability in asphyxiated term neonates. J Perinatol. 2007;27(6):365-370.

Naess A, Nilssen SS, Mo R, Eide GE, Sjursen H. Role of neutrophil to lymphocyte and monocyte to lymphocyte ratios in the diagnosis of bacterial infection in patients with fever. Infection. 2017;45(3):299-307.

Naeye RL, Shaffer ML. Postnatal laboratory timers of antenatal hypoxemic-1schemic brain damage. J Perinatol. 2005;25(10):664-668.

Nakajima W, Ishida A, Lange MS, Gabrielson KL, Wilson MA, Martin LJ, et al. Apoptosis has a prolonged role in the neurodegeneration after hypoxic ischemia in the newborn rat. J Neurosci. 2000;20(20):7994-8004.

Nelson KB. The epidemiology of cerebralpalsy in term infants. Ment Retard Dev Disabil Res Rev. 2002;8(3):146150.

Palmer C, Roberts RL, Young PI. Timing of neutrophil depletion influences long-term neuroprotection in neonatal rat hypoxic-ischemic brain injury. Pediatr Res. 2004;55(4):549556.

Papile LA, Baley JE, Benitz W, Cummings J, Carlo WA, Eichenwald E, et al. Hypothermia and neonatal encephalopathy. Pediatrics. 2014;133(6):1146-1150.

Rocha-Ferreira E, Hristova M. Plasticity in the neonatal brain following hypoxic-ischaemic injury. Neural Plas. 2016;2016:4901014.

Sarnat HB, Sarnat MS. Neonatal encephalopathy following fetal distress. A clinical and electroencephalographic study. Arch Neurol. 1976;33(10):696-705.

Shankaran S, Woldt E, Koepke T, Bedard MP, Nandyal R. Acute neonatal morbidity and long-term central nervous system sequelae of perinatal asphyxia in term infants. Early Hum Dev. 1991;25(2):135-148.

Wang J, Lu Q. Expression of $\mathrm{T}$ subsets and mIL-2R in peripheral blood of newborns with hypoxic ischemic encephalopathy. World J Pediatr. 2008;4(2):140-144.

Winerdal M, Winerdal ME, Kinn J, Urmaliya V, Winqvist $\mathrm{O}$, Aden U. Long lasting local and systemic inflammation after cerebral hypoxic ischemia in newborn mice. PLoS One. 2012;7(5):e36422.

Winerdal M, Winerdal ME, Wang YQ, Fredholm BB, Winqvist $\mathrm{O}$, Aden U. Adenosine A1 receptors contribute to 
immune regulation after neonatal hypoxic ischemic brain injury. Purinergic Signal. 2016;12(1):89-101.

Received for publication on $10^{\text {th }}$ December 2018

Accepted for publication on $30^{\text {th }}$ April 2019 